\title{
Research on Public Satisfaction Index Model of Urban Management Informatization
}

\author{
Liang $\mathrm{Hu}^{*}$, Jin Wen, Hongmei Yu, Yuchi Zhu and Ying Du \\ Department of humanities and management, Jiangxi Police College, Nanchang, China \\ *Corresponding author
}

\begin{abstract}
This paper takes the city management informatization public satisfaction as the research object, using the theory of customer satisfaction evaluation of mature, through the analysis of factors affecting public satisfaction, city construction management informatization public satisfaction index model, and finally solve the inspection and evaluation parameters of the model using the partial least squares method, and provide suggestions for information construction of city management.
\end{abstract}

Keywords-urban management; informatization; public satisfaction; index model

\section{INTRODUCTION}

The public satisfaction index is a new economic index to evaluate the quality of economic operation from the perspective of public or social demand. It plays a very important role in the real understanding of the needs of the public and the objective evaluation of the quality and service of the public. The public is the beneficiary of urban management information, but also to promote the level of urban management information [1][2]. The public's dependence on urban management information directly reflects the level of urban management information services, and their satisfaction is a measure of the quality of urban management services. Therefore, the establishment of city management informatization public satisfaction index system, regularly evaluated objectively and comprehensively and accurately to the city management information, is conducive to the city management departments to understand and grasp the needs of the public, the rational allocation of limited resources, promote the city management and service innovation, to provide the basis for the city management departments to improve its quality of service[3][4][5].

\section{URBAN MANAGEMENT INFORMATION PUBLIC SATISFACTION FACTORS}

Public satisfaction is a concept which is based on the research of customer satisfaction in the public sector. According to the definition of satisfaction, we can see that the public satisfaction refers to the degree of satisfaction of the public to the government, which is based on the understanding of the government's work [6][7]. This city management informatization public satisfaction refers to the public in the process of enjoying information service, a service of city management information for the overall perception of the city management information service expectations and the actual get city management information service after comparing with that of the subjective evaluation[8][9].

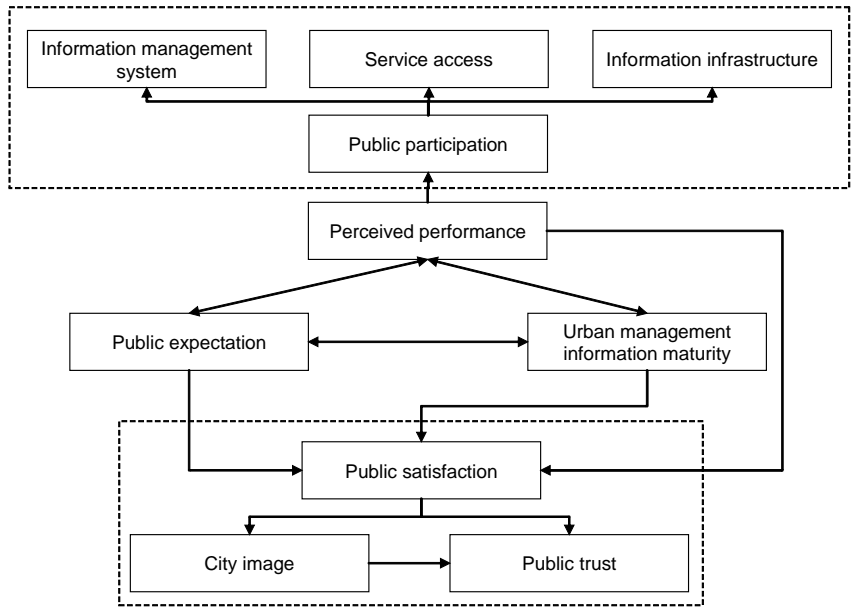

FIGURE I.

URBAN MANAGEMENT INFORMATIZATION PUBLIC SATISFACTION INDEX MODEL

The model consists of 10 latent variables and 28 variables can be measured, the model of public satisfaction with the core variables, including Public expectations and 7 antecedents and the City image and Public trust variables and 13 correlation results.

\section{A. Public Expectation}

The public expectation of urban management information is composed of two parts. The former refers to the basic needs of the public that should be satisfied from the urban management information services; the latter refers to the expectations beyond the basic expectations, the public is not aware of the existence of the demand. As the public becomes more and more familiar with the needs of urban management information services, the basic needs of the public and the expectations of the potential demand is also increasing. Therefore, the "public expectation" as the first variable in the process of public acceptance of urban management information service has a certain impact on satisfaction.

\section{B. Perceived Performance}

Perceived performance is formed by the public's contact with the urban management information service, which is the interactive result of the public expression needs and the urban management department to provide information services. Service contact is a necessary condition for the formation of satisfaction, so this paper will be the public perception of urban management information as a key driver of satisfaction, which is the key factor of public satisfaction. 


\section{Urban Management Information Maturity}

The public life background, educational level, personal values are different because there are differences on the level of city management informatization level expected public satisfaction impact factor, so not all depends on the public's perception of performance, an important factor of city management itself informatization maturity model and satisfaction.

\section{URBAN MANAGEMENT INFORMATIZATION PUBLIC SATISFACTION INDEX MODEL}

Based on the CSI model, the author uses multidimensional measurable variables to measure the latent variables. In determining the measurable variables, measurable variables should be possible as latent variables can explain and measure the corresponding attention selected, but also to follow the principles of establishing the index system, to ensure the operability of the system variables. In this paper, the measurable variables of the public satisfaction index model for urban management informatization are shown in Table 1.

\section{TABLE I. URBAN MANAGEMENT INFOMATIZATION PUBLIC} SATISFACTION INDEX MODEL

\begin{tabular}{ll}
\hline \multicolumn{1}{c}{ First Level Index } & \multicolumn{1}{c}{ Second Level Index } \\
\hline \multirow{2}{*}{ Public expectation } & Public demand expectation \\
& Reliability expectation \\
& Informatization level expectation \\
& System service items \\
& System coverage \\
Information & System response speed \\
management system & System feedback efficiency \\
& System connectivity \\
& Public cognition \\
Service access & Convenience level \\
& Public use frequency \\
Information & Facility improvement \\
infrastructure & Terminal perfection \\
& Quality of managers \\
Public participation & Interactivity \\
& Social supervision mechanism \\
Perceived & Opportunities for public participation \\
performance & General perception of public use \\
Urban management & Breadth of information application \\
information maturity & Depth of information application \\
& General public satisfaction \\
& Satisfaction with expected quality \\
& Satisfaction with ideal quality \\
& Satisfaction with public opinion \\
& Channel for filing complaints \\
& Speed of efficiency \\
& Public trust in government \\
& Public support for the government \\
\hline Publion & \\
&
\end{tabular}

This empirical study is based on a city in China. The validity of the public satisfaction index model of urban management information is examined, and the correlation coefficient between the latent variables and the measurable variables and the latent variables in the model is obtained. The survey is mainly based on the questionnaire survey of the web site. A total of 500 questionnaires were distributed, and the valid questionnaires were collected in 448 cases. The basic situation of the samples was shown in Table 2.

TABLE II. QUESTIONNAIRE BASIC STATISTICS

\begin{tabular}{|c|c|c|}
\hline Items & Type & Ratio \\
\hline \multirow{3}{*}{ Education } & Junior high school and below & $18.5 \%$ \\
\hline & High school & $38.4 \%$ \\
\hline & Bachelor degree and above & $43.1 \%$ \\
\hline \multirow{6}{*}{ Occupation } & Civil servant & $20.6 \%$ \\
\hline & Business owners & $11.3 \%$ \\
\hline & Enterprise staff & $36.7 \%$ \\
\hline & Teachers and researchers & $19.6 \%$ \\
\hline & Students & $2.3 \%$ \\
\hline & Other & $9.5 \%$ \\
\hline \multirow{3}{*}{ Gender } & Male & $56.2 \%$ \\
\hline & Female & $43.8 \%$ \\
\hline & Under 20 years old & $15.9 \%$ \\
\hline \multirow{3}{*}{ Age } & 20-40 years old & $35.3 \%$ \\
\hline & $40-60$ years old & $31.4 \%$ \\
\hline & Above 60 years old & $17.4 \%$ \\
\hline \multirow{5}{*}{ Household income } & Less than 30 thousand yuan & $38 \%$ \\
\hline & 30-70 thousand yuan & $34.8 \%$ \\
\hline & $70-100$ thousand yuan & $9.2 \%$ \\
\hline & $100-150$ thousand yuan & $7.6 \%$ \\
\hline & Greater than 150 thousand yuan & $10.4 \%$ \\
\hline
\end{tabular}

In order to test the reliability of the collected data, SPSS15.0 software was used to test the reliability and validity of the 28 items. The test results are shown in Table 3 and Table 4.

1) There is a weak correlation between public satisfaction and public expectation (-0.1142), that is, the higher the public's expectation of urban management information, the lower the public satisfaction.

2) In the other two potential variables that affect the public satisfaction, perceived performance is larger (0.6746), and the maturity of urban management information is less (0.5358).

3) Public satisfaction has a positive impact on city image (0.3127) and public trust (0.3968).

TABLE III. RELIABILITY ANALYSIS

\begin{tabular}{cc}
\hline Reliability coefficient & Number of items \\
\hline 0.913 & 28 \\
\hline
\end{tabular}


TABLE IV. RESULTS OF VARIABLE VALIDITY

\begin{tabular}{clc}
\hline No. & \multicolumn{1}{c}{ Variable } & Variance \\
\hline 1 & Public demand expectation & 0.643 \\
2 & Reliability expectation & 0.657 \\
3 & Informatization level expectation & 0.612 \\
4 & System service items & 0.714 \\
5 & System coverage & 0.698 \\
6 & System response speed & 0.598 \\
7 & System feedback efficiency & 0.650 \\
8 & System connectivity & 0.735 \\
9 & Public cognition & 0.713 \\
10 & Convenience level & 0.605 \\
11 & Public use frequency & 0.590 \\
12 & Facility improvement & 0.674 \\
13 & Terminal perfection & 0.723 \\
14 & Quality of managers & 0.731 \\
15 & Interactivity & 0.593 \\
16 & Social supervision mechanism & 0.679 \\
17 & Opportunities for public participation & 0.582 \\
18 & General perception of public use & 0.801 \\
19 & Breadth of information application & 0.637 \\
20 & Depth of information application & 0.768 \\
21 & General public satisfaction & 0.749 \\
22 & Satisfaction with expected quality & 0.681 \\
23 & Satisfaction with ideal quality & 0.725 \\
24 & Satisfaction with public opinion & 0.739 \\
25 & Channel for filing complaints & 0.696 \\
26 & Speed of efficiency & 0.826 \\
27 & PUBLIC TRUsT IN GoveRNMENT & 0.695 \\
28 & Public support for the government & 0.634 \\
\hline & & \\
\hline
\end{tabular}

\section{DISCUSSION AND FUTURE WORK}

Urban management is a systematic project to promote the urban economic and social development, the implementation of the public satisfaction strategy in the city management of information technology to improve the level of city management, plays an important role in promoting social and economic coordinated development of city. In this paper, based on the analysis of the factors affecting the public satisfaction of urban management information, the public satisfaction index model of urban management information is constructed.

Construction of city management informatization public satisfaction index model of science, helps to improve city management information transparency, the public satisfaction research city information management more scientific and standardized, contribute to the city management departments to understand the effect of various factors on city management informatization public satisfaction, to accurately grasp the needs of the public, targeted to enhance public satisfaction.

\section{ACKNOWLEDGMENT}

This author's work is supported by JiangXi Research on teaching reform of higher education(JXJG-15-19-3), JiangXi
Science and technology research project of Education Department(GJJ151193), JiangXi Social Science Planning Projects during the 12th Five-Year Plan(14TQ05), JiangXi University Party Building Project(16DJQN065).

\section{REFERENCES}

[1] Cheng Jianwen. New ideas of urban management[J]. Urban management, 2002 (2): 32-33. (in Chinese)

[2] Xu Lin. Dream of the king study of management information system for performance evaluation of city[J]. Technology development company, 2013,32 (12): 98-100. (in Chinese)

[3] Zhang Jian. A preliminary study on the realization of urban management informatization[J]. Chinese standardization, 2004 (5): 2326. (in Chinese)

[4] Zhang Daoshun. Study on the planning and construction of urban information sharing database[J]. Intelligent building and urban information, 2004 (4): 44-49. (in Chinese)

[5] Zou Kai. An Empirical Study on public satisfaction index model and empirical research of government services for micro-blog[J]. Journal of Xiangtan University: Philosophy and Social Sciences Edition, 2016 (1): 75-79. (in Chinese)

[6] Mao Dan. Methods of measurement and evaluation of public satisfaction and problems[J]. Chinese Journal of public health management, 2016 (5): 639-642. (in Chinese)

[7] Chen Bo. External evaluation of government budget performance indicators: an investigation based on public satisfaction[J]. Qinghai Social Sciences, 2016 (4): 99-105. (in Chinese)

[8] Zhang Miaomiao. A review of theoretical research on public satisfaction at home and abroad[J]. Chinese Business Theory, 2016 (30): 147-148. (in Chinese)

[9] Zheng Fanghui. An Empirical Study on the factors affecting the overall performance of the government[J]. Journal of Tianjin Administration College, 2014,16 (1): 40-48. (in Chinese) 